\title{
GENERATIONAL TRANSITION IN FAMILY BUSINESS AND THE DISTRIBUTION OF CAPITALS IN SOCIAL REPRODUCTION STRATEGIES
}

\begin{abstract}
The paper presents the results of research into the problem of succession in family business in the broader perspective of social reproduction strategies. Based on Pierre Bourdieu's theoretical habitus-field framework and strategies of reconversion of capitals, it identifies preconditions for successful succession, the strategies of reconversion applied and the structure of capital transfers along with transgenerational change. The author recognizes habitus as the pivot element of explanation, the specific adequacy of capital structure, individual preferences and aspirations with situational potential, and general structural rules.
\end{abstract}

Keywords: succession, family business, reproduction, habitus, economic capital, cultural capital

\section{INTRODUCTION}

Family businesses are important market actors, responsible for a substantial share of GDP production and a vast percentage of employment in most capitalist economies [Morck et al. 2000; Neuberg, Lank 1998]. They are usually thought of as small and medium enterprises; nevertheless, they represent from over $30 \%$ up to even 45\% of the Fortune 500 [Aronoff et al. 1996; Villalonga, Amit 2006; 2009; Shleifer, Vishny 1986] and one third of the S\&P 500 [Anderson, Reeb 2003]. Such facts demand more scientific attention.

* Dr; e-mail: lukasz.trembaczowski@us.edu.pl 
The growing body of research and publications in the area of family business has been dominated by questions of succession [Benavides-Velasco et al. 2013]. This is not surprising, considering that succession is the biggest challenge for the continuity of a family business while succession within a family plays a central role in maintaining its character. Most of the research on transgenerational succession in family business is conducted within management studies, assuming the institutional economy approach. However, fragmented results and the lack of any general theory of generational transition lead to some major questions about the limits of the disciplines' outlook [Sharma et al. 1997: 7]. Some authors point out that theorems adopted in succession research fail to meet specific theoretical requirements and can therefore be recognised merely as fancy etiquettes or descriptive terms of an interesting phenomenon [Giambatista et al. 2005]. Leaving aside the question of the necessity of a general succession theory, one can point to the problem of deficits of general knowledge of transgenerational succession, in particular, its economic and social consequences, modes of inheritance of companies and assets, as well as historical continuity [Safin et al. 2014: 50]. That would explain why researchers introduce such variables as values, interpersonal communication, family culture and bonds into the management-study perspective [Dunemann, Barrett 2004]. Adapting learning, life cycle or game theories as well as some psychological concepts is common and directly postulated by some of the researchers in this field [Sharma et al. 2004].

As generational transition in family business becomes more and more interor multidisciplinary, there is also a place for important contributions regarded from the sociological perspective. An important example of combined sociological and economic research was delivered by Krzysztof Safin, Jacek Pluta and Barbara Pabjan [2014], who adopted Peter Blau's social exchange theory to model generational transition, in terms of integration and opposition, as well as the institutionalisation of the exchange process. Such an adaptation resulted in some valuable findings; however, a general theoretical comment is also required. The selection of Blau's theory seems justified since a more extensive economical and utilitarian perspective of human behaviour was adopted. However, it simultaneously shifts the focus of such a theoretical approach to the reciprocal exchange of benefits and it limits behavioural motivation to the expected returns. Consequently, it offers less of a sociological perspective of the whole generational transition problem than one might expect, as the authors missed some important sociological aspects of social structure and hierarchisation.

Taking the subordination of sociological considerations to managerial studies and the institutional economy as a weakness of such analysis, one could reason- 
ably ask about an alternative. This may be found in a change of approach, to look at succession processes not as part of a wider perspective of business transfer but to adapt the sociological perspective in the first place, which would allow for the recognition of individual dilemmas and choices in a wider context of structural settings and limitations [Mills 1959]. This would appear to be an important contribution because, so far, family businesses have never received the sociological attention they deserve [Lajstet, Królicka 2017: 56-57]. Such a perspective may be found in adapting the theory by Pierre Bourdieu, redefining succession in terms of class reproduction strategies. In other words, such a theoretical approach shifts the perspective from business and enterprise to the practice of social relations and the structure of possessed capitals. The analysis of succession viewed as reproduction has to take into consideration several aspects that comprise the social structure and the structure of the field in which entrepreneurs are set.

\section{THE EVOLUTION OF THE ECONOMIC FIELD AND THE (RE)BIRTH OF THE PROPERTY CLASS}

The reconstruction of capitalist relationships and the emergence of the entrepreneurial class after 1989 fits into the narrative of the return to the development tracks of mid-war Poland from which it was derailed by World War II and the subsequent communist era [Bucholc 2012: 14]. Despite the wishful character of collective ideas about the golden era of the entrepreneurs, deconstructed by Marta Bucholc, the idea of ruptured continuity is at the roots of the widely shared concept of the rebirth of the entrepreneurial class and the creation of capitalism without capitalists [Eyal, Szelenyi, Townsley 1998]. In Poland, the rebirth is predominantly associated with the so-called Wilczek's law ${ }^{1}$, which aimed at liberating the entrepreneurial spirit of Poles, hitherto suppressed under the centrally controlled economy, also appearing as a cornerstone of liberal, promarket reforms. This well-known picture turns more complicated if one asks why Wilczek's law was actually possible. Bourdieu's habitus-field concept may provide a deeper insight into the process. "A field in Bourdieu's sense is a social arena within which struggles or manoeuvres take place over specific resources or stakes and access to them" [Jenkins 1992: 52]. Reference to the concept of the field allows for a description of economic activities within a centrally planned economy without any market concept being pinpointed, i.e., access to restricted goods within the shortage economy as a certain position within the economic field,

1 The Economic Activity Act of $23^{\text {rd }}$ December 1988, commonly known as Wilczek's law. 
allowing for the reconfiguration of such goods to other forms of economic capital (material and financial) as well as into symbolic capital. Replacing the market concept with that of the economic field does not draw the researcher's attention to the rupture between the centrally planned economy and the market system, but instead allows for the concept of gradual reconfigurations of the economic field. According to Jenkins, reconstruction of a field requires three distinct operations: the relationship of the economic field to the field of power must be discussed, the reconfigurations of the structure of the field's position due to clashes within the field over dominance must be described, and habituses of agents within the economic field must be analysed [Jenkins 1992: 53].

The relationship of the economic field towards the field of power can be described in terms of an autonomisation process. The enforcement of the communist regime led to the development of another type of capital, political capital [Bourdieu 1998: 16], and the heteronomous principle of hierarchisation that contained the economic field within the field of power. However, the periodical reappearance of political fractures and economic crises resulted in the growing autonomy of the economic field [Gardawski 2001]. Such autonomy was gained within the administrative class (known as the "party nomenklatura") over the dominant principles of hierarchisation [Domański 2015: 90-93]. While the technocratic party elite gained more and more influence [Gardawski 2013: 57], one could observe the development of heterodoxy of the primacy of the economy over politics. The economic field, contained within the field of power, while possessing autonomy with respect of it, started heading towards total autonomy from the field of power. The autonomous principle of hierarchisation within the economic field was thus the nucleus of the logic of the field during the transformation era that reigned unchallenged when the economical field achieved total autonomy with respect to the laws of the politics. ${ }^{2}$ In other words, Wilczek's law was only a consequence of earlier changes and a catalyst for ongoing processes. Such general changes of the field created space for the (re)birth of the property class after 1989.

The birth of the property class must be discussed in consideration of the modal trajectories of access to the economic field and the rising position of the entrepreneur.

2 Whether it gained such an autonomy is a different issue. Even now, control of the state over some sectors of the economy (i.e. mining or power generation) and the relative weakness of the employers' organisations (such as Business Centre Club or Lewiatan) together with their limited political influence [Jasiecki 2002: 239-248] raise questions about the scope of economic field's autonomy or even a halt/reverse in the process of autonomisation. 
The first trajectory would appear to be the reconversion of the political capital (undergoing rapid inflation at the turning point of the transformation process) into economic capital. Such a trajectory corresponds to the concept of gaining property rights by nomenklatura, developed in the literature on the topic [Staniszkis 1990; Wasilewski 1995]. Leaving aside discussions of the scale of the phenomenon, the scope of such reconversion is worth considering. In terms of the middle strata of the administrative class, the privatisation included the acquisition of some assets of state-owned companies (and the most valuable workers). Gardawski calls it the acquisition of hardware [Gardawski 2013: 63].

The second trajectory would be the reconversion of cultural capital, both incorporated and institutionalised, into economic capital. One can recall here the concept of "privatisation of software", understood as taking over contracts and know-how of state-owned companies which were cornerstones of the businesses started up by former executives and employees of state-owned companies [Gardawski 2013: 63]. This trajectory was also followed by entrepreneurs outside the former nomenklatura. These people were graduates of technical universities with a certain level of expertise, although they had little or no political capital to reconvert. However, they possessed enough cultural capital, i.e., relevant knowledge, to start their own enterprises in favourable conditions.

The third trajectory would be the reconfiguration of the economic capital gathered either through quasi-legal/illegal ways (i.e. contraband or commercial tourism) or earned abroad (joint-venture companies). Such investments were necessary because those relatively small amounts of capital allowed for long-term profits unavailable in any other way. Depending on the amount of such assets, they allowed people either to start their own businesses or to acquire unfinished privatisations of state-owned companies.

Agents that entered the economic field and took the role of entrepreneurs brought in different capitals which had to be converted into economic capital and different habituses formed in other fields with other logics. Moreover, in the beginning, the transformation process led to anomie, and the logic of the economic field was far from transparent or fully fledged. In fact, the rules of the field were worked out by agents operating in that field during acts of mutual cooperation, competition, exchanges of blows or favours. It was the founding generation of the property class that contributed to the creation of the logic of the economic field. However, when reconfiguring the economic field, entrepreneurs developed new habituses that fitted the field's logic. Now, as the founding generation is going to transfer their enterprises into the hands of a younger generation, the problem of class reproduction appears to be central. 


\section{THE QUALITATIVE STUDY - METHODOLOGICAL ISSUES}

The results discussed in this paper are based on research conducted by the author in 2016 and 2017. The main focus of the research was on perceiving succession as a reproduction strategy of the property classes, formulating several research questions:

- Why was succession adopted as a strategy of class position reproduction?

- What conditions must be satisfied for succession to become a successful reproduction strategy?

- What other strategies, other than succession, were considered and why were they abandoned?

- What is the structure of capitals transfers from one generation to another?

- What investments did the senior generation make to prepare for succession?

- Was the cultural capital deficit made up for in educational investments?

The main approach of the research was based on an attempt to overcome business owners' perspective bias that was repeated in earlier studies [Surdej, Wach 2010; Safin et al. 2014, Pawlak 2014]. Since intergenerational succession in family business involves two main actors, the doyen ${ }^{3}$ and the successor, they deserve the same attention, as the succession perspective can differ substantially, depending on the role played by the actors throughout the analysed process [Safin et al. 2014: 197]. To ensure comparability of the results gathered from the older and successor generations, it was assumed that interviews would be held with the doyens and the successors of the same family enterprise. The target was to interview only those companies that have already accomplished their transgenerational succession or are advanced in that process (a successor already held an executive position in the company).

The research comprised in-depth interviews with the original owners and successors of twelve family businesses from five voivodships. This resulted in twenty-six registered interviews. Together, it gave thirteen interviews with doyens (one female and twelve males) and the same number of interviews with the successors (two females and eleven males) ${ }^{4}$. Seven of the successors were aged from 21 to 30, four were in the range between 31 and 40, and two were over 40. In the group of doyens, most (seven) were between 61 and 70 years, four were younger (51 to 60 years), and two were over 70 years old.

Since there is no generalised database concerning family businesses available in Poland, and even estimations of their general population depend on an adopted

\footnotetext{
In the article, the term "doyen" is used to describe owners from older generation.

4 In one company, two interviews were carried out with the doyens and two interviews with the successors.
} 
definition [Safin 2007: 46-57], no representativeness criteria were adopted. The earlier research, especially that of a quantitative character, proved the insignificance of the sector in which a company operates [Suredej, Wach 2010] or the regional differences of such succession processes [Safin et al. 2014: 193]. Consequently, neither sector nor region of registration was taken into account while selecting respondents. Even though sector can differentiate the family business conditions, like experienced risks [Trembaczowski 2016], market position, networks of cooperation and other factors, the sector was not adopted as a sampling criterion, but it was referred to in the analysis. ${ }^{5}$ At the beginning of the research, the size of the family business was taken as the main differentiating variable (with reference to the distinction between businessman and craftsman [Gardawski 2013]). Because of the difficulties in reaching the respondents, the best option seemed to be snowball sampling. This assumption was soon verified in practice, because the respondents were somewhat reluctant to provide contacts to other business families which had also undergone succession or avoided the promise to contact the researcher with such families. Following the steps of the earlier research carried out in Poland, the author cooperated with the Family Business Institute and the Family Enterprise Initiative to select respondents ready to take part in the research. Eventually, purposive sampling was adopted. All the interviewed companies originated from the SME sector, and four companies were chosen in each size category: micro (1-9 employees), small (10-49 employees) and medium (50-249 employees). The in-depth interviews were based on similar lists of questions, and most topics were raised in interviews with both the doyens and their successors. However, some questions, like those about the company history, were asked only to the founders. The doyen and the successor were interviewed separately.

Carrying out the research proved to be very difficult, not only because of the general reluctance of family businesses to take part in the research, but also because of the adopted criteria and subject of the research. Firstly, the topic of succession overlaps areas of family life, wealth or business strategy, none of which business families tend to discuss. Secondly, the insistence on interviewing respondents from both generations, founding and succeeding, resulted in many refusals (it proved hard to convince respondents from both generations). Third, to avoid the family members agreeing on answers, the interviews were conducted consecutively, and the presence of both the respondents in the company at the same time proved to be an obstacle. All these difficulties impeded the research and extended the data gathering period.

5 The sector of operation appeared to be important in the case of entry barriers to the sector or consolidation processes but was not further specified in this paper. 
The discussed research constitutes a part of a larger study that hopefully will allow for a deeper and broader analysis of the succession problem. However, the data gathered so far allowed us to verify some assumptions and shed light on the process of succession considered in a wider social context of class position reproduction. Since there had been no research comparing the doyens' and their successors' perspective on succession in family businesses conducted in Poland, or the participation of owners and successors was marginal and the qualitative study was only of an auxiliary character, it seems justified to publish the preliminary results [Lewandowska 2014].

\section{SUCCESSION AND INHERITANCE - TWO PERSPECTIVES OF REPRODUCTION}

The research concept presented in this paper shifts the interest from simple generational changes within the company to the wider perspective of social reproduction strategies. With such an approach, focusing only on the company would be misleading. To overcome the enterprise perspective bias, the question asked by Krzysztof Safin was particularly important: Who should inherit, and what? [2014:51] Indeed, this question is the problem that all the parents face, especially if they have more than one child. Business families are no exception here; however, the question is more complicated. It appeared during the research that the doyens consider succession within a family business as part of a wider process of inheritance, and answers to questions about the successor were always given within a wider family wealth context. One of the respondents put it straightforwardly:

I want my son and my daughter to enter the company by the end of the year. I don't know how big the share would be [...] I would just like as the saying goes "to pay them off" [the other two children who do not inherit company]. Me, not them. Not those [children] who will enter the company. [...] I want to do it. (Doyen 1_1)

Economic capital is central to the property class positions and no wonder; this very capital is considered mostly when the doyens think of providing for their children's future. In other words, limiting succession only to the enterprise is inappropriate, because in the doyens' experience, the question is about the children inheriting the family wealth and the family enterprise is only one of the assets. Parents, at least at the declarative level, tend to divide, as Krzysztof Safin calls it, "succession mass" equally between children. Passing on a company to an heir, specific transfer schemes - especially regarding economic capital - are 
required which take into consideration other children who do not inherit part of the company, so as to make the transfer just. This can take different forms, like funding the building of a house, passing on an old building that used to be the headquarters or transferring start-up capital to newly established companies of the children that do not inherit the family business (all examples taken from interviews). Such an outlook can be noticed in statements of both the doyens and the successors. As one of the latter put it:

There was a major management problem in the company and as some of the assets were indivisible, we had to straighten things out. (Successor 7)

Striving to support children in the future, an expression that the doyens very often stated during interviews also referred to children from other relationships. One of the respondents declared that he had separated part of the company's assets (that can function as an independent enterprise) for his son from a previous relationship. It is worth mentioning that his company was started with his second wife, and their two sons are the successors. In other words, balancing the inherited assets is one of the key factors taken into consideration in the succession process. Even if the company is to be run by siblings who found their niches or specialisations, parents have to face the question of balance. One of the successors revealed that she nearly resigned from her leading role in the company when her parents insisted on transferring shares to the third sister who was already running her own business. The balance of just shares, as the parents see it, must therefore meet with the successors' view of the matter. In such conflict situations, successors that took the leading role refused to work together with all the siblings (in all cases, the maximum number of successors engaged in the company was two, despite the actual number of children). The argumentation was based on the disproportion between the work done by those who are involved in the company and the distribution of profits. In fact, all conflicts recorded in the interviews between siblings regarding succession concerned the work-ownership overlap. While successors stressed that work and ownership should be connected, and they did not accept sibling shareholders who did not contribute to the company's operations, it was hard to get the opinions of the founders, as they were very reluctant to discuss any conflicts between the siblings, choosing instead to talk about the harmony that was eventually achieved.

The shift of attention from company to family relationships adapted in the research revealed an alternative outlook of the doyens' heirdom strategy compared to the typology of strategies for the relationship between the company and the family. Even though all such strategies adapted in the interviewed companies 
can be merely reduced to two types, "company from generation to generation" and "co-ownership of the family with the management of one family member" [Sułkowski, Marjański 2009: 160], they take place within wider family inheritance and social position reproduction strategies. This appears visible when the "left out" children are considered; they are usually marginalised in analysis of the relationships between the family and the company.

The problem of strategies adapted for and by children who do not inherit a company reveal how the succession alternatives were valued by the doyens. It also reveals what real strategies were adapted to reconfigure the capitals so as to keep the social position gained by the parents' generation. Issues of pride or reluctance to share such information can be accepted as an indicator of the value assigned to different strategies. A "normal" alternative to succession would be running one's own enterprise, with or without the help of the parents. Quite often, it is the only strategy that the doyens took into consideration when starting another business only for the purpose of passing it on to a second child. One successor revealed how obvious such a solution is:

My father [established another enterprise for my sister] because we knew no other option to do it any other way. (Successor 3)

For the founders, it was obvious that the children who were left out of the succession would start their own businesses as a reproduction strategy. When asked about it in the interviews, it was common for the founders to say, "Of course he has his own business". In other words, a modal strategy for children left out of the succession was to reproduce their position within the dominant class (with high levels of economical capital, and relatively lower of cultural one) with the use of economic capital, transferred from the older generation, therefore allowing the children to (re)enter the field by establishing their own business. With reference to the distinction between the "programmed" and "seeking" biographies developed by Hanna Palska [2002: 99-104], one can categorise the described reproduction strategies as "programmed" or "family made".

Reconfiguration strategies directed outside the richest in the economic capital fraction of the dominant class to its fraction with the higher levels of the cultural capital, like professionals or academics [Bourdieu 1984], were relatively rare (only three cases). Both parents and siblings were proud of those family members who had entered that pathway, and they valued their educational successes highly. Such a reconversion of economic capital into cultural capital allowed to make up for the family's cultural capital deficit (a nouveau riche syndrome) and legitimised somehow the gained position. However such cases did not change 
the inclination to the main reconversion strategy. The best example of such an attitude was the case of the son left out in the succession who was finishing his medical studies. Both interviewees, father and son (who inherited the company), declared independently of each other, that they expect he (the son left out during succession) would run his own medical clinic and they were going to help him to start up. For them ownership of own business was the measure of their son's/ brother's future success, not the profession he was to perform. The intergenerational movement between class fractions follows the hierarchisation principle of the field, and allows for the anticipation of a relatively high proportion in the second generation of members of the possessing fractions who originated from the same fraction [Bourdieu 1984:120].

\section{SUCCESSION IN A FAMILY BUSINESS AS A TRAJECTORY OF THE RECONFIGURATION OF CAPITALS}

Any direct discussion of succession needs the context of alternative reproduction strategies. Alternative pathways of capital reconversion and reproduction strategies can be traced in those successors who did not enter the family enterprise directly, but who nevertheless showed different professional experiences and returned to the family business when reconversion attempts failed. Those cases transcend the distinction between "seeking" and "programmed" biographies (Palska 2002), because they merge individual attempts to construct their own independent career with "family made" dispositions. What should be added here is the fact that real attempts to work outside the company were observed only in the case of deep labour markets (in more industrialised and urbanised areas) while in shallow ones (less urbanised and industrialised) they tended to end up as merely intentions [Kozek 1993: 56] ${ }^{6}$. Therefore, real attempts prove more important as they reveal different strategies, which usually end in failure.

One of the successors had taken several jobs, mostly of a subordinate character, and he described his experience in a very blunt way:

I had my ass kicked so hard, I haven't been afraid of any job since then. (Successor 5)

Even though he eventually held a better position in low-level management, his decision to return was based on evaluating the capitals he had and the achieved position relative to the rising trajectory he expected within the family business.

Similarly, a more successful respondent, who was developing his corporate career, eventually abandoned it after he missed a promotion. That is especially in-

6 The classification of labour markets was done with the help of an expert. 
teresting in the face of declarations made by the entrepreneur's children who point to corporations as preferred career pathways [Lewandowska, Tylczyński 2014].

The successor's father stated that he had failed due to a lack of connections or relationships necessary for upward promotion. Although deficits in social capital and failure to be promoted played a role, the successor pointed to a habitus mismatch in his declaration about leaving the corporation:

For the entrepreneur's son, there is no chance in a corporation: influence on decisions - none, speed of decision making - none. I saw no connection between what I was doing and the effects - it made no sense. [...] I could have done things that would have increased sales except I couldn't because I had to do some stupid things. (Successor 6)

Successors who returned to the family businesses did not consider it a failure but a sound choice. Decisions were based on their calculations, because they found out that the relative position in the family enterprise they could reach after their return was relatively higher than what they had already achieved and, as one successor stated:

it would require years to achieve that in a corporation. (Successor 6)

A similar motivation is behind decisions made by successors who had never attempted to have a professional career outside the company. That was most often associated with difficulties in finding a position after graduation, a motivation also declared by those who really wanted to run the family business:

when we graduated, it was hard to get any job [...] so why look around for a job when you can find one in your own backyard? (Successor 10)

Successors who had never attempted any career outside the family enterprise and, according to their declarations, had come to the family business only temporarily, eventually got caught up in its affairs. The opportunity to work independently and in a position relatively higher than what they could have achieved somewhere else, revised their attitudes:

I have more and more respect for my father, [...] Before, I thought of it as a small shitty business with just a few employees, but when I saw how it worked, and what we had to cope with to survive [...] and how much there was for me to do [...] I decided to stay. (Successor 12)

The element that usually was the catalyst for the return to the family business was marriage. Nearly all respondents who decided to give up their initial plans and careers did so when they needed more stabilisation, and this was associated 
with marriage. Such a return to a safe haven is not only associated with a secure position guaranteed by the status of being the owners' son or daughter but predominantly with the competencies they had gained throughout the years of helping/ working in the family company before the actual process of succession begins:

Eventually, you ask yourself, what else you can do? (Successor 10)

Most valid answers came from those successors who had never considered leaving the family business and were committed to working there. The successors often repeated:

I always knew [...] I would run the family business. (Successor 2)

Succession, in such cases, was treated as obvious because indeed:

it was natural (Successor 10)

and

that's how it turned out. (Successor 7)

Ironically, the usually - but not always - very smooth successions were most difficult to analyse because they were described as if there was no agency of the successor or the doyen. Since practice is "intrinsically defined by its tempo" [Bourdieu 1977: 8], the key to understanding such a situation is to be found at a point earlier than the succession process itself. Nearly all of the successors recalled their childhood, when the company used to be their playground and "helping in the company" - another keyword used by both parents and successors to describe the successor's work, even after they were employed on a full-time basis - was inseparable from other housework, like dusting, washing dishes or mowing the lawn. This is echoed in the successors" notion of "our company", no matter whether they were speaking about their childhood days or the present. This extended family home was a place where they were engaged in most of the simple tasks, like sweeping the floor or weighing and labelling commodities, through more advanced ones like operating a conveyor belt or helping in vehicle repairs, to even taking control of the company when their parents went on holiday. No wonder it was difficult for the interviewees to pinpoint the exact moment the succession started or decisions were made, because they were inscribed in their daily practice. Bourdieu does not "accept that practice can be understood solely in terms of individual decision-making on the one hand, or as determined by supra-individual 'structures' as the metaphysics of objectivism would have it, on the other" [Jenkins 1992:45]. The bridging concept of habitus is what needs to be recalled in order to explain succession as a process steeped in social practice, despite the decision-making and external conditions. The latter are important, but 
habitus becomes essential to understand smooth successions because "it ensures the active presence of past experiences, which, deposited in each organism in the form of schemes of perception, thought and action, tend to guarantee the 'correctness' of practices and their constancy over time, more reliably than all formal rules and explicit norms" [Bourdieu 1990:54].

The formation of habitus begins at the very beginning of life. The doyens often spoke of their children's natural curiosity and the will to be involved in family affairs, which only needed not to be suppressed. The creation of the entrepreneurial habitus, reflecting direct and indirect choices, decisions and dispositions, would be the central notion to explain why one's own company, either inherited or established by oneself, is such a predominant career path. The disposition to work on one's own is found in a statement that can represent many similar answers given by the respondents:

I am the kind of man who doesn't like to work for others. (Successor 4)

This can explain why some reject profitable jobs abroad to run their small business which offers them

much more satisfaction than any other job (Successor 7)

or abandon a career as a therapist to discover that working in a family enterprise is

the job of their dreams. (Successor 12)

In some very special moments, when festive or official narratives are abandoned, and respondents reflexively analyse their life, the habitus dispositions are almost tangible. Explaining his educational choices (managerial studies for someone who decided to be a tour operator) and finding that the reason for doing so was simply rationalisation, one respondent explained that such

things happen at the level of instinct. Instinct doesn't tell me, but rather it's done. (Successor 5)

Such "unexplained coincidences" happened to all respondents who found, often to their surprise, that their education perfectly suits the needs of the family company. In other words, it is habitus that is responsible for adapting succession as the strategy of class reproduction, since it appears as an adaptation mechanism, ensuring harmony between subjective aspirations and the possibility of accomplishing them [Jacyno 1997: 27]; however, habitus itself is not enough for a successful succession. On the one hand, habitus dispositions do not exclude deliberation or rational decisions, while on the other hand, working for a family business is not only about calculating the position, remuneration and favourable 
conditions it gives. The doyens often say that their successors don't earn much (Doyen 9) and usually work more than their employees (this, however, may differ from case to case [Więcek-Janka 2014: 46]). In other words, incompatibility of successors' dispositions to "external" milieus of corporate work, allow to understand their higher valuation of work for one's own over job in someone else's company.

The habitus' dispositions do not mean that succession is deterministic process. The situation of the company, or as Krzysztof Safin calls it, "succession potential", does play a part and is taken under consideration.

Calculating a company's potential and capabilities to support two or three families is the main external condition that results in limiting succession to a maximum of two successors. This is a rational calculation for both sides, the doyen's and the successor's. The company may appear too small to provide a living for the parents and all the siblings' families, but

big enough to foster new enterprises (Successor 4)

for the left out children.

\section{TRANSFER OF CAPITALS}

A popular tool to describe the trajectory of transfers presented in the Polish literature on succession in family business is the $3 \mathrm{~W}$ model, which stands for knowledge, power and property (in Polish, all three words start with "w") [Budziak 2012] $]^{7}$. The data gathered in the interviews confirm the general framework of this model, with some specific features of individual companies. This model provides a useful basis for analysing the transfer of capitals in a business family. As emphasised at the beginning of the analysis, the specificity of the applied approach lies in the shift of focus from enterprise to relationships, where the transfer of capitals is central to understanding both the reproduction of positions and the succession itself.

Knowledge - stands for the incorporated cultural capital. Even when companies which do require specific knowledge and professional education are taken into consideration, cultural capital is not associated with any formal recognition, e.g., a university degree or the title of engineer; nor does it play any prestigious role (i.e. not to stand out from the other employees) but it refers to hard knowledge.

7 However, some authors differentiate between the rise and education of a successor and the transfer of power and ownership, recognised as individual key problems or thresholds [Sułkowski, Marjański 2009: 39]. 
In other words, with such educational investments, it is not the institutionalised cultural capital that is important for succession, but rather the incorporated one. This can, of course, comprise specific and specialist knowledge necessary in the area the firm operates in, but predominantly it covers knowledge about how to run a company.

Transfers of such knowledge are of both a cognizant and incognizant character. Deliberate transfers of knowledge start the moment the founders decide to pass their company on to their heirs. During the interviews, both the doyens and the successors described such moments when the parent informed his potential successor about the details of the company's operations that the other employees were unaware of, or that the successor would not know given his/her current formal position in the company.

The incognizant transfer of knowledge starts much earlier and is interwoven in the practices of the family business. The doyens were often proud of the successor's early engagement and their specific knowledge or skills, which might be considered unique when compared to their peers' knowledge of such things as ceramics or car construction. The successors often emphasised that the company was present all the time in the family home and the parents' discussions revolved around it, so their knowledge about the company's affairs was acquired spontaneously. But the main channel of knowledge transfer was through practice - working/ helping in the company. As pointed by one of the successors:

there is no one in our company working on the plastics and aluminium lines. It was only me. No one here will ever stump me. (Successor 5)

The cognizant and incognizant knowledge transfers, or practical skills gathered throughout the years of helping and expertise gained from formal education, sometimes combine to create a successor tailored to take over the company. An example would be one of the successors, who first played with clay used in company's factory - he was firing fabulous [ceramic] dinosaurs (Doyen 4), then worked in the factory and learned the crafts from senior employees and eventually studied ceramics at the Technical University. The practical knowledge of materials gave him great advantages over his peers during his studies - his professor said she had never had a student like him - one who could feel and understand what clay was (Senior 4). Such a merge of specialist knowledge and practical skills won him the great respect of all the employees, because he was not a boss demanding an explanation of every single problem but one that could come up with solutions. According to the doyen's statement, it would probably be impossible to find a manager who showed such a rare mix of competencies. 
Power is not specified by Bourdieu as a different capital but as a function of the possessed capitals and recognition of them. Since power and control are based on ownership, this would refer to the subtle intertwining of the two. However, formal power in a company is what really exceeds transfer of the whole property. Entering a company, successors are usually recognised as heirs and gain a specific position (as forthcoming boss and owner) associated with liking and sometimes malevolence. Before the whole power is transferred to the hands of a successor, he usually heads one of the company's departments - which is recognised in the literature as an "advanced functional" phase of the succession process [Longenecker, Schoen 2002: 61-64; Sułkowski, Marjański 2009: 42]. This time is essential to build up the social capital, both internally and externally.

Building the internal social capital begins, to a certain extent, simply by being present in the company (the company as an extended family home). However, to gain more, yet limited power, successors must build their own background, a group of employees that recognise their leadership and later become trusted co-workers. The doyens sometimes stated that their successors were very harsh and demanding and they found it inappropriate. The change or evolution of their attitudes came along with the recognition of their position: after he engaged the employees in developing a strategy, I saw that his attitude evolved and I was assured I had made a good decision [transferring all power into the son's hands]. (Doyen 3).

The building of external social capital is connected with the heir constantly being exposed to clients and partners, even before the formal succession takes place, so as to broaden the successor's network of contacts. One of the successors put it straightforwardly:

my father wants me to attend business meetings and conferences to meet people [...] I don't feel like it, but I know he is right. (Successor 2)

This transfer, however, is a complicated network of relationships. On the one hand, in the local environment, the successors discover their position changes from the owner's son to the boss of the family business:

I see that people changed their attitudes towards me, for example, in the town hall. (Successor 5)

On the other hand, transfers of social capital are sometimes accomplished in a very subtle way. One of the founders described his experiences running a jewellery business when he was relatively young, hiring an older man for security. He soon found out that clients and partners thought the older man was his father, which gave his company an air of reliability since jewellery is 
a somewhat conservative business. Now, having passed his company on to the children, he still appears on the premises to talk to older clients and partners, giving credibility to the whole enterprise.

The reconversion of economic capital into social capital is more complicated, yet when performed by the founders, it allows the successors to enter into the network of contacts. The meaning of the family name is central here. The doyens have built some credibility (sometimes at high costs) which is associated with the family name, and this element is inherited most easily. In other words, the family name alone offers the heir a credit of trust, yet the successor's trustworthiness must be confirmed by his own deeds [Hardin 2002, Sztompka 1999: 70-78].

Property is, in fact, a form of economic capital. It plays a central role in the entrepreneur's position, while the whole succession process should end with the transfer of ownership. This, however, is a most sensitive moment and every interviewed company has a different situation, ranging from the parent keeping the whole ownership, even without any explicit declaration of passing shares on to the children, who in fact run the business, through passing some stocks of the family business to the heirs with or without the controlling stake in the parent's hands, to the transfer of the whole company, keeping a small, independent part of the business in the parent's hands. The doyens were, in fact, rather reluctant to transfer the ownership rights and sometimes declared they would keep the controlling stake for the rest of their lives.

The reluctance to transfer ownership is, to some extent, associated with the control of the successor's behaviour and of the whole enterprise: I hold $80 \%$ of the shares in the company. I'm the chairman of the board because I want to control where the company is heading (Doyen 3). Limited economic resources, together with limited ability to guarantee a certain level of revenues, are often the bottleneck of the whole process and all the conflicts recorded during the interviews were associated with the ownership-work relationship. As successors demand that their siblings work in the company if they hold the shares, they have the opposite expectation towards their parents. For them, it is obvious that their parents would be owners or retain shares, but they would rather choose independence in their work. The ownership-power relationship overlaps the ownership-work one which can be traced in the conflicts around the successors' remuneration:

I got $20 \%$ of the shares because I told my father: If you want me to work as a professional manager, pay me as much as you would have to pay to a professional manager. (Successor 3) 
In other words, the link between work and power is established during the succession process. It is symptomatic that after succession occurs, the definition of the successors' involvement changes from "help" to "work", which is associated with certain revenues and more often with shares, since help is unpaid while work must be paid for. The work, however, is connected with power because

to have power in a business is the key to controlling it - to hold it in real terms. (Successor 4)

However, to have real power, one has to keep the ownership in one's own hands. That is why in some of the interviewed families, one child received the controlling stack of shares and controls the company while the other just "helps".

\section{CONCLUSIONS}

The shift from the economic perspective on management succession in the family business to the sociological approach adopted in this paper places the reproduction of class position through succession at the core of the considerations. The concentration on generational transition, referring to Bourdieu's theory, places succession in family businesses in the perspective of the agents' habitus dispositions and the capitals they possess, as well as their practices and the choices they make. Focusing on the role and impact of the reconfiguration of capitals for the succession process allows us to draw several conclusions. Bearing in mind the limited research sample size, the presented conclusions ought to be considered tentative and preliminary. The concluding comments can provide inspiration for further research and the formulation of hypotheses.

First, a wider parental perspective of inheritance may be observed, containing succession itself. The choice of a successor cannot be reduced to the selection of the best candidate but should be analysed from the wider perspective of family relationships. The pursuance of a fair or balanced transfer of economic assets is the cornerstone of succession decisions. Such a fair transition is negotiated not only between parent and child but also between parents ${ }^{8}$, between siblings and between generations, and it requires general agreement to maintain family order.

Secondly, the analysis of reconversion strategies applied by the children left out of the succession, as well as alternative paths abandoned upon returning to the company, allow us to suppose that running their own company is the main

8 One interview comprised both parents (the co-owners of the company) and two of their children, which revealed deep discrepancies between the spouses' outlook on the fair transfer of assets. 
strategy of position reproduction. This path was also considered by those who eventually succeeded in the succession process and are now heading their family business. In other words, succession fits into the modal reproduction trajectory, which means positioning oneself in entrepreneurial positions. That can be achieved within a family business or outside of it.

Third, the decision to return to a family business can be traced both in a habitus mismatch to alternative pathways and calculations of possessed capitals, as well as achievements compared to the position they might expect to walk into in the family business. Such returns were accompanied by the stabilisation of the successor's family life. It remains unclear to what extent such decisions were preceded by failures on alternative pathways, as not all of the siblings eventually run the family company.

Fourth, one can enumerate the conditions which have to be satisfied if succession is to become a successful reproduction strategy. Spanning decisions and structural conditions, habitus is central to understanding that circumscription and certain dispositions are indispensable for succession to occur. On the structural conditions' side, effective succession potential must exist in the form of a functioning company that can sustain the incomes of the business family at a specified level. However, to last and flourish, that company must be recognised as one with potential. This turns the discussion to the issue of successor's decision, referring to the evaluation of the working conditions and individual career building perspectives in the light of the amount of capitals held. This again goes back to some general conditions of the regional labour market, available alternatives, and the amount of capitals needed to maintain the inherited position or the potential upward trajectory. Recognising all those conditions in the light of habitus allows the gap to be bridged, because some "rational" calculations of possessed capitals that make succession a sound decision are hidden from the agents. The practice of "helping" in the company appears to contribute to the creation of dispositions that are responsible for perceiving the whole succession process as a natural and obvious choice.

Fifth, applying Bourdieu's theory allows us to distinguish habits as the central notion to describe succession in a family business. "Being the product of a particular class of objective regularities, the habitus tends to generate all the 'reasonable', 'common-sense' behaviours (and only these) which are possible within the limits of these regularities, and which are likely to be positively sanctioned because they are objectively adjusted to the logic characteristic of a particular field, whose objective future they anticipate" [Bourdieu 1990: 55-56]. The reasonable, sound choice of a succession strategy is, therefore "obvious" in comparison with the rejected career paths that are "not for the likes of us". Habitus combines specific 
conditions of the field (i.e. economic capital as a requirement needed to enter the field) and individual preferences or aspirations (readiness to enter the field and become an entrepreneur).

Sixth, a structure of capitals transfers (cultural, social and economic) can be tentatively distinguished which, to a certain extent, overlaps the widely accepted $3 \mathrm{~W}$ model (knowledge, power, property). The transfer of cultural capital covers three main aspects: the practical skills needed in the production or the services offered by a company (gained mostly throughout childhood and the teenage period), operational knowledge (incognizant knowledge from early involvement and cognizant transfer after formal employment in the company) and specialist knowledge, bringing together their own experiences and formal education. The transfer of social capital is associated with the transfer of power, because the very moment it starts, the transfer of contacts, networks, partners and clients is initiated. The transfer of power, only partial at the beginning (at the advanced functional phase) and complete after the early succession phase [Longenecker, Schoen 2002: 61-64; Sułkowski, Marjański 2009: 42]), allows the internal and external social capital to develop. The internal social capital comprises the employees who recognise the successor's leadership and tend to be his trusted co-workers later on, while the external social capital is built on the family name and the brand's reputation. The transfer of economic capital is entangled with power relations, where the old rule of "power following ownership" [Drucker 2000: 59] is confirmed. The transfer of economic capital is postponed by the older generation and is rarely complete. Three main forms of reconfiguration may be distinguished: the parent's complete ownership with an appointed successor, a parent's co-ownership, usually holding the major stock of shares, and the transfer of the whole company to the heirs, securing their incomes in the form of dividends, or a cooperating, yet extraneous business.

Seventh, further analysis allowed us to suppose that the doyens' readiness to transfer capitals is "symmetrical and opposite" [Bourdieu 1984: 120] to the importance of capital in reproducing the position. The direction of transfers follows from the least important for the field (cultural capital) to the most important (economic capital). The founders had no problems sharing knowledge with their children and were usually pleased with the children's interest in the company's affairs. They often declared that they made an effort to stimulate such interest or allowed their children to follow it even at a very young age. Sharing power was more difficult because if the transfer is made too early or too late (the Prince Charles syndrome), it can have disastrous consequences. Moreover, as 
the doyens used to play a decision-making role, they had difficulties leaving that position. In some cases, they kept the deciding vote to decide on the company's development. This overlaps with their reluctance to transfer the economic capital. Postponing the ownership transfer is connected with both their will to exercise control over the general direction of the business as well as the desire to consume profits guaranteed by the company.

Consideration of both outlooks, the doyens' and the successors', with reference to Bourdieu's theoretical approach, allows us to present the interweaving of the parental strive to secure the children's future with the businessmen's care for the company they created on the one hand, and the habitus dispositions, and reconfigurations and investments of capitals in order to reproduce the parent's social position on the other. The formation of the younger generation's habitus was twofold - within the family and the company, simultaneously. Unlike their parents, the young generation possessing class's habitus is their primary habitus. Approaching habitus in terms of adequacy of subjective aspirations and prospect of realising them, one can explain succession as a modal reproduction trajectory. Therefore, one can transcend the "returning class" perspective [Gardawski 2001] to consider the class that has returned.

\section{REFERENCES}

Anderson Roland C., David M. Reeb. 2003. "Founding-family ownership and firm performance: Evidence from S\&P 500". The Journal of Finance 58(3): 1301-1328.

Aronoff Craig E., John L. Ward, Joseph H. Astrachan. 1996. Family business sourcebook II. Marietta GA: Business Owner Resources.

Bourdieu Pierre. 1977. Outline of a theory of practice. Cambridge: Cambridge University Press.

Bourdieu Pierre. 1984. Distinction. A critique of the judgment of taste. Cambridge MA: Harvard University Press.

Bourdieu Pierre. 1990. The logic of practice. Cambridge: Polity Press.

Bourdieu Pierre. 1998. Practical reason. Stanford CA: Stanford University Press.

Bucholc Marta. 2012. Konserwatywna utopia kapitalizmu. Etyczne iluzje międzywojennego kupiectwa. Warszawa: Wydawnictwo Naukowe PWN.

Budziak Tomasz. 2012. Sukcesja w rodzinie biznesowej. Spojrzenie praktyczne. Warszawa: Wydawnictwo Poltext.

Benavides-Velasco Carlos A., Cristina Quintana-García, Vanesa F. Guzmán-Parra. 2013. "Trends in family business research". Small Business Economics 40(1): 41-57.

Domański Henryk. 2015. Czy w Polsce sa klasy społeczne? Warszawa: Wydawnictwo Krytyki Politycznej.

Drucker Peter F. 2000. Zarzadzanie w XXI wieku. Warszawa: Muza

Dunemann Mark, Rowena Barrett. 2004. Family business and succession planning. A review of the literature. Melbourne: Faculty of Business and Economics, Monash University. 
Eyal Gil, Iván Szelenyi, Eleanor Townsley. 1998. Making capitalism without capitalists. Class formation and elite struggles in post-communist Central Europe. London - New York: Verso.

Gardawski Juliusz. 2001. Powracajaca klasa. Sektor prywatny w III Rzeczpospolitej. Warszawa: Wydawnictwo IFiS PAN.

Gardawski Juliusz. (ed.). 2013. Rzemieślnicy i biznesmeni. Właściciele matych $i$ średnich przedsiębiorstw prywatnych. Warszawa: Scholar.

Giambatista Robert C., W. Glenn Rowe, Suhaib Riaz. 2005. "Nothing succeeds like succession: A critical review of leader succession literature since 1994". The Leadership Quarterly 16(6): 963-991.

Hardin Russell. 2002. Trust and trustworthiness. New York: Russell Sage.

Jacyno Malgorzata. 1997. Iluzje codzienności. O teorii socjologicznej Pierre'a Bourdieu. Warszawa: Wydawnictwo IFiS PAN.

Jasiecki Krzysztof. 2002. Elita biznesu w Polsce. Drugie narodziny kapitalizmu. Warszawa: Wydawnictwo IFiS PAN.

Jenkins Richard. 1992. Pierre Bourdieu. London-New York: Routledge.

Kozek Wiesława. 1993. „Rynek pracy. Socjologiczne interpretacje podstawowych pojęć”. Studia Socjologiczne 128(1): 51-64.

Lajstet Joanna, Beata Królicka. 2017. Firmy rodzinne jako przedmiot badań naukowych. In: Firmy rodzinne. Ludzie-relacje-wartości. Beata Królicka (ed.), 45-59. Toruń: Wydawnictwo Naukowe Uniwersytetu Mikołaja Kopernika.

Lamont Michele. 1992. Money, morals and manners: The culture of the French and American upper-middle class. Chicago-London: The University of Chicago Press.

Lamont Michele. 2001. Culture and identity. In: Handbook of sociological theory. Jonathan H. Turner (ed.). New-York: Kluwe Academia/Plenum Publishers.

Lewandowska Adrianna. 2014. „Ciagłość przywództwa jako wyzwanie w procesie sukcesyjnym firm rodzinnych". Przedsiębiorczość i Zarządzanie 15(7): 89-102.

Lewandowska Adrianna, Tylczyński Lukasz. 2014. Barometr sukcesyjny i prognozowanie ścieżki kariery dzieci z firm rodzinnych. Poznań: Instytut Biznesu Rodzinnego.

Longenecker Justin G., John E. Shoen. 2002. Management succession in the family business. In: Family Business Sourcebook. Craig E. Aronoff, Joseph H. Astrachan, John L Ward. (eds), 61-66. Georgia: Family Enterprise Publishers.

Mills Charles W. 1959. The sociological imagination. London: Oxford University Press.

Morck Randall K., David A. Strangeland, Bernard Yeung. 2000. Inherited wealth, corporate control and economic growth: the Canadian disease? In: Concentrated corporate ownership. Working paper 6814, Morck Randall K. (ed.), 319-371. Cambridge MA: National Bureau of Economic Research.

Neuberg Fred, Alden G. Lank. 1998. The family business: Its governance for sustainability. London: Palgrave-Macmillan.

Palska Hanna. 2002. Bieda i dostatek. O nowych stylach życia w Polsce końca lat dziewięćdziesiatych. Warszawa: Wydawnictwo IFiS PAN.

Pawlak Agnieszka. 2014. „Sukcesja w polskich przedsiębiorstwach rodzinnych”. Przedsiębiorczość i Zarządzanie 15(7): 55-67.

Safin Krzysztof. 2007. Przedsiębiorstwa rodzinne. Istota i zachowania strategiczne. Wrocław: Wydawnictwo Akademii Ekonomicznej.

Safin Krzysztof, Jacek Pluta, Barbara Pabjan. 2014. Strategie sukcesyjne polskich przedsiębiorstw rodzinnych. Warszawa: Difin. 
Sharma Pramodita, James J. Chrisman, Jess H. Chua. 1997. "Strategic management of the family business: Past research and future challenges". Family Business Review 10(1): 1-35.

Sharma Pramodita, James J. Chrisman, Jess H. Chua. 2004. "Succession planning as planned behavior: Some empirical results". Family Business Review 16(1): 1-15.

Shleifer Andrei, Robert W. Vishny 1986. „Large shareholders and corporate control”. Journal of Political Economy 94(3): 461-488.

Staniszkis Jadwiga. 1990: "Political capitalism in Poland". East European Politics and Societies 5(1): 127-141.

Sułkowski Lukasz, Andrzej Marjański. 2009. Firmy rodzinne. Jak osiagnąć sukces w sztafecie pokoleń. Warszawa: Poltext.

Surdej Aleksander, Krzysztof Wach. 2010. Przedsiębiorstwa rodzinne wobec wyzwań sukcesji. Warszawa: Difin.

Sztompka Piotr. 1999. Trust. A sociological theory. Cambridge: Cambridge University Press.

Trembaczowski Lukasz. 2016. Zaufanie i ryzyko w doświadczeniu przedsiębiorców. Katowice: Wydawnictwo Uniwersytetu Śląskiego.

Villalonga Belén, Raphael Amit. 2006. "How do family ownership, control and management affect firm value?" Journal of Financial Economics 80(2): 385-417.

Villalonga Belén, Raphael Amit. 2009. "How are U.S. family firms controlled?" The Review of Financial Studies 22(8): 3047-3091.

Wasilewski Jacek. 1995. Formowanie się nowej elity. Jak wiele nomenklatury zostało? W: Ludzie i instytucje. Stawanie się ładu społecznego, A. Sułek, J. Styk (eds.), 409-418. Lublin: Wydawnictwo UMCS.

Weber Max. 1978. Economy and society. An outline of interpretative sociology. Berkeley-Los Angeles-London: University of California Press.

Więcek-Janka Ewa. 2014. „Ile rodziny w firmie rodzinnej. Wyniki badań w Wielkopolsce”. Przedsiębiorczość i Zarządzanie 15(7): 37-53.

\section{Łukasz Trembaczowski}

\section{PRZEMIANA POKOLENIOWA W FIRMACH RODZINNYCH A STRUKTURA ROZKŁADU KAPITAŁÓW W STRATEGIACH REPRODUKCYJNYCH}

\section{Streszczenie}

Artykuł prezentuje wyniki badań poświęconych sukcesji w firmach rodzinnych rozpatrywanej w szerszej perspektywie strategii reprodukcji pozycji klasowych. Odwołując się do teorii Pierre'a Bourdieu a konkretnie jego koncepcji habitusu-pola i strategii rekonwersji kapitałów, tekst analizuje warunki zajścia sukcesji, zastosowane strategie reprodukcji oraz transfery poszczególnych kapitałów w trakcie zmiany pokoleniowej w firmach rodzinnych. Badania wskazują na habitus jako kluczowy element wyjaśniający szczególną odpowiedniość struktury kapitałów, indywidualnych wyborów i aspiracji z potencjałem sukcesyjnym przedsiębiorstwa, a ogólniej strukturalnymi regułami i ograniczeniami reprodukcji.

Słowa kluczowe: sukcesja, firmy rodzinne, reprodukcja, habitus, kapitał ekonomiczny, kapitał kulturowy 